\title{
FAST DISINFECTION OF CONTAMINATED STORMWATER USING PERACETIC ACID
}

\author{
Dário Souza Santos ${ }^{1 *}$, Luiz Alberto Cesar Teixeira ${ }^{2}$ and Isaac Volschan Jr. ${ }^{3}$ \\ ${ }^{1}$ Rio de Janeiro Federal University, Department of Water Resources and Environmental, Av. Athos da Silveira \\ Ramos, 149, Centro de Tecnologia - Bloco D, Sala 202, Cidade Universitária - Rio de Janeiro - RJ - Brasil \\ 2Pontifícia Universidade Católica do Rio de Janeiro, Department of Chemical and Materials Engineering, and \\ Peróxidos do Brasil Ltda. (Solvay Group), Rua Marquês de São Vicente, 225, Rio de Janeiro - RJ - Brasil
}

Received 9 April 2021; received in revised form 10 June 2021; accepted 30 June 2021

\begin{abstract}
This work evaluates the performance of peracetic acid (PAA) for the disinfection of stormwater runoffs contaminated by domestic sewage with the objective of using the collecting systems as contact reactors for in-situ disinfection. PAA is increasingly being used as a substitute for chlorination in the disinfection of wastewaters because of its rapid degradability and the absence of chlorinated organic by-products. In Brazil, and despite the adoption of the separator system in sewage systems, there is a large amount of domestic effluents that are piped directly into the stormwater systems, contributing to the contamination of water bodies. The efficiency of the disinfection of Escherichia Coli was evaluated by applying different doses $\left(2,5\right.$ and $\left.10 \mathrm{mg} . \mathrm{L}^{-1}\right)$ of PAA with short contact times $(2,5$ and 10 minutes) in real stormwater samples collected at three different points of the stormwater system of the city of Rio de Janeiro. Trials were performed simulating the conditions and flow times available in the stormwater sewers. The results were excellent, with removals up to $5 \log$ units with $10 \mathrm{mg} . \mathrm{L}^{-1}$ peracetic acid and 2 minutes contact time. Where there was available a contact time of at least 5 minutes, a dose of $5 \mathrm{mg} . \mathrm{L}^{-1}$ was sufficient.
\end{abstract}

Keywords: Peracetic acid, disinfection, stormwater, urban drainage systems, urban pollution.

(C) 2021 Journal of Urban and Environmental Engineering (JUEE). All rights reserved.

\footnotetext{
*Correspondence to: Dário Santos E-mail: dariosouzasantos@gmail.com
} 


\section{INTRODUCTION}

In Brazil the sewerage systems separate sewage from stormwater sewers which are designed exclusively to carry residual urban runoff waters. This type of system requires the existence of interceptors for dry weather conditions and overflows, which are designed mainly based on the rainwater flow for the particular region. But in practice, many of those sewers end up transporting a mixture of residual urban runoff waters and sewage. Frequently this leads to contamination of water receiving bodies used by the population for recreational bathing posing a serious public-health problem.

Data made available at the last official sanitation data survey collected by the Brazilian Government (Pesquisa Nacional de Saneamento Básico no Brasil) carried out in 2017, demonstrate that in urban areas collection of sewage is only $52.4 \%$, of which only $73.7 \%$ are adequately treated (SNIS, 2019). The reality is that waste is not adequately treated in terms of the environmental impact, but simply moved away from the source.

At the national level, there is no standardization regarding pathogenic microorganism discharge in water bodies. Only 4 of the 16 Brazilian states establish limit values for the total coliform parameter at state level. However, the minimum level of recreational bathing water quality is defined by the Brazilian Standard (CONAMA 274/2000), which limits E. Coli count to less than $800 \mathrm{MPN} / 100 \mathrm{~mL}$ (in the water receiving body).

In order to minimize the environmental impact caused by the discharge of contaminated stormwaters in rivers, lakes and the sea, it would be useful to take advantage of the time interval the effluent stays in the rainwater collecting pipes to carry out in-situ disinfection.

Traditional technologies of wastewater disinfection such as UV radiation and ozonisation would require significant capital investment and maintenance if installed in an existing network. Chlorination in various interception points in the stormwater collection network using either $\mathrm{NaClO}$ solution or $\mathrm{Ca}(\mathrm{ClO})_{2}$ tablets would be effective and require low investment, but would bring further limitations when considering the generation of various chlorinated organics as ecotoxic by-products (Coyle et al, 2014). The wide composition variation of contaminated stormwater streams and the high volumes of effluent drainage require a disinfectant that is not only effective, easy to use, low in cost, and fast acting to rapidly knock out microorganisms in an in-situ treatment, but also does not leave toxic residuals in the receiving aquatic environment.
A possible alternative disinfectant for consideration is PAA - peracetic acid $\left(\mathrm{CH}_{3} \mathrm{CO}_{3} \mathrm{H}\right)$, which is the peroxide of acetic acid. Its oxidation capacity is higher than that of chlorine or chlorine dioxide. In its commercial form it is a quaternary equilibrium mixture of acetic acid, hydrogen peroxide, peracetic acid and water (reaction 1). PAA solutions are colourless, have a pungent odour similar to that of vinegar and are totally soluble in water.

$$
\mathrm{CH}_{3} \mathrm{CO}_{2} \mathrm{H}+\mathrm{H}_{2} \mathrm{O}_{2}=\mathrm{CH}_{3} \mathrm{CO}_{3} \mathrm{H}+\mathrm{H}_{2} \mathrm{O}
$$

(reaction 1)

PAA combines the characteristics of the active oxygen of a peroxide linked to a molecule of acetic acid and is an organic peroxide. For chemical stability reasons (Block, 2001; Kitis, 2004; ECHA, 2016) it is commercially available in liquid solution at concentrations up to $15 \% \mathrm{w} / \mathrm{w}$ of PAA.

Since 2000 the US-EPA (2000) regards PAA as a possible alternative for disinfection of wastewaters because it does not form disinfection by-products. Since then PAA disinfection of wastewaters has been growing worldwide.

As for the specific treatment of stormwaters, Volschan et al (2017) reported a case of temporary insitu disinfection with PAA conducted during the Olympic and Paralympic Games of Rio de Janeiro of 2016. Positive results were obtained by adding peracetic acid in doses as high as $20 \mathrm{mg} . \mathrm{L}^{-1}$ directly to points of access (manholes) in the drainage network which discharges into a lagoon where water sports competitions took place. At the discharge points that were monitored, colimetry showed virtually no E. Coli, and no cases of infection of athletes were reported.

It is suggested that the active oxygen of PAA promotes protein denaturation, affecting the osmotic capacity of the cell membrane of microorganisms by breaking the cell wall and the thiol (-SH) and sulphur (S-S) bonds that exist in proteins, enzymes and metabolites. Virus inactivation by addition of PAA was also reported in studies. It is believed that the inactivation mechanism is a result of damage caused to the superficial structure of the virus, such as the protein coat or the attachment site, at the protein layer of the host cells (Koivunen \& Heinonen-Tanski, 2005; Luukkonen et al, 2014). It is also reported that both peracetic acid and hydrogen peroxide in low concentrations are effective for killing various highly pathogenic virus like the V. Cholerae (Baldry et al, 1995), and the recent SARS-CoV2 (US, 2020); this is especially relevant because the virus has recently been detected in wastewaters during the present pandemic (Warish et al, 2020). 
Several studies of the disinfection efficiency in wastewaters, (Atasi et al, 2001; Kitis, 2004; Koivunen \& Heinonen-Tanski, 2005; Cavallini et al, 2012; Andreoli et al 2013; Chhetri et al, 2014; Coyle et al, 2014; Au et al, 2016) mention inactivation values of Escherichia Coli and Enterococcus greater than $3 \mathrm{log}$ units, in effluents with an initial count of $10^{2}$ to $10^{6} \mathrm{MPN} / 100 \mathrm{~mL}$. In those studies various doses were tested, from $2 \mathrm{mg} . \mathrm{L}^{-1}$ up to $100 \mathrm{mg} . \mathrm{L}^{-1} \mathrm{PAA}$, but there is a general consensus that 2 to $15 \mathrm{mg} \cdot \mathrm{L}^{-1}$ are sufficient to reach satisfactory levels of disinfection, provided sufficient contact time is allowed.

The products resulting from the decomposition of PAA are: acetic acid, hydrogen peroxide, oxygen and water. Peracetic acid decomposition may occur in one of three ways: spontaneous decomposition, hydrolysis and catalytic decomposition induced by transition metal ions (Kitis, 2004; ECHA 2016; ECETOC, 2001). Chhetri et al (2014) evaluated the concentration profiles of peracetic acid in effluents derived from combined systems (CSOs) representing the concentration profiles of PAA with time, for 3 different dilutions and $\mathrm{pH}$ values between 5.18 and 8 . The authors concluded that natural decomposition of PAA is slow (22\% after 300 min. for an initial $7.81 \mathrm{mg} . \mathrm{L}^{-1}$ and $2 \%$ after $180 \mathrm{~min}$. for an initial 1.19 mg.L- ${ }^{1}$ ).

Studying the effect of $\mathrm{pH}$ and salinity, Coyle et al. (2014) obtained very good E. Coli reduction results using moderate doses of PAA ( 5 to $15 \mathrm{mg} . \mathrm{L}^{-1}$ ) and contact times of 2 to 10 minutes in simulated wet weather flow waters. Test solutions were made up by diluting samples taken from a wastewater treatment plant with $\mathrm{pH}$ in the range 7.0 to 7.7. They found that while the $\mathrm{pH}$ had little influence, the concentration of $\mathrm{Cl}^{-}$ions had more influence on the initial demand of PAA, as salinity appears to induce decay of the initial dose in the first 2 minutes.

As to the effect of TSS (total suspended solids), McFadden et al (2017) determined the influence of TSS on the disinfection efficiency of sodium hypochlorite and PAA in CSOs effluents. Falsanisi et al (2008) state that it is the solid particles with a diameter greater than $10 \mu \mathrm{m}$ that provide protection to the bacteria because of the particle association phenomena. It was concluded that PAA was more efficient for all the TSS fractions evaluated.

Regarding the effect of organic content and metals, effluents with high levels of COD (chemical oxygen demand) and metals require higher doses of PAA for disinfection. This increase is due to the consumption of the PAA by oxidation of organic matter, which may include the more persistent or recalcitrant pollutants, and by the catalytic effect the metals exert upon the spontaneous decomposition of peroxides (Falsanisi et al, 2008).
As it is with disinfectants in general, the factors that have greater influence on the efficiency of the inactivation are biocide concentration and contact time. Studies of the disinfection of raw and treated wastewater indicate that the highest percentage of inactivation occurs during the first 10 minutes. Generally, PAA concentrations added to the microorganisms are far higher than the lethal dose required (Kitis, 2004; Luukkonen et al, 2015). Because PAA is an organic compound, it has the disadvantage of increasing the effluent organic load, potentially enabling bacterial regrowth, mainly due to acetic acid. However, Antonelli et al (2013) report that the regrowth is insignificant.

Considering the formation of by-products, several authors concluded that the amount of DBPs (disinfection by-products) generated by adding peracetic acid is very low, even in saline environments where the concentration of ions is higher (Dell'Erba et al, 2005). Nurizzo et al (2005) assessed the formation of DBPs resulting from the addition of PAA in secondary wastewater reclaimed for reuse in agriculture. In that study they noted that for doses of PAA between 6 and $30 \mathrm{mg} . \mathrm{L}^{-1}$, phenol can act as a receptor of free radicals. On the other hand, the addition of PAA to aqueous solutions containing humic acid rich in chlorides did not result on an increase of adsorbable halogenated organic compounds (AOX), or of total halogenated organic compounds (TOX), which suggests that chlorides are not oxidised by PAA to $\mathrm{HClO}$. Nurizzo et al also observed that if the wastewater is rich in bromide, an increase occurs in AOX and bromoform, indicating that PAA oxidises bromides to $\mathrm{HBrO}$, generating brominated by-products. The authors concluded that in spite of the high bromide concentration, in the presence of low organic matter and low oxidation potential DBPs do not form. Interestingly, no increase was observed in THMs (Nurizzo et al, 2005).

In terms of its ecotoxicity, PAA can show acute toxicity to aquatic species, independently of their trophic levels. Studies carried out by the European Centre for Ecotoxicology and Toxicology of Chemicals (ECETOC) report that the level (concentration) of PAA without observable effects (NOEL) for 120 hours contact time for the organism Selenastrum capricornutum was $0.13 \mathrm{mg} . \mathrm{L}^{-1}$ and that $\mathrm{EC}_{50}$ (effective concentration that stops the growth of the organism in $50 \%$ of the population) was $0.18 \mathrm{mg} . \mathrm{L}^{-1}$. Peracetic acid is also toxic to Daphnia magna, with a value of $\mathrm{EC}_{50}$ between 0.5 and $1 \mathrm{mg} . \mathrm{L}^{-1}$ for 48 hours contact time. For fish in general, toxicity was lower; for a contact time of 96 hours, LC $_{50}$ (lethal dose that kills $50 \%$ of the population) varied between 0.9 and $3.3 \mathrm{mg} \cdot \mathrm{L}^{-1}$ (ECETOC, 2001). Overdoses of PAA under laboratorycontrolled conditions proved to be highly toxic to algae 
(Selenastrum capricornutum) and aquatic invertebrate (Daphnia magna) and moderately to low toxic for fish (Bell et al, 2015).

Given the context and the favourable features of PAA, it was the objective of the present work to investigate the use of PAA applied in low doses to disinfect stormwaters contaminated with sewage in conditions of short contact times (as low as 2 minutes) with the purpose of allowing the use of stormwater drainage systems as in-situ contact-reactors, and thus preventing pollution and improving recreational bathing of water bodies that receive runoff discharge.

\section{Materials and Methods}

The study was carried out in the city of Rio de Janeiro, in the hydrographic basin of the Rodrigo de Freitas lagoon, close to Ipanema (total area of $23.68 \mathrm{~km}^{2}$ and population of 168,218 . The local climate is tropical with mean annual precipitation between 1,100 and $2,100 \mathrm{~mm}$. Runoff from rain over this region drains into the lagoon and the surrounding beaches carrying contamination, which affects recreational bathing.

Due to the variability of the runoff and in an attempt to represent different drainage areas in the region of study, we selected three collection points in different sewers. Once the samples were collected, basic water quality characteristics were determined. The monitored parameters, following the findings of works listed in Kitis's review (2004) included the initial E. Coli count $\left(\mathrm{C}_{0}\right), \mathrm{pH}, \mathrm{BOD}, \mathrm{TSS}$, Turbidity and Salinity. After PAA dosages the final $E$. Coli (C) was measured by colimetry with the Colilert ${ }^{\circledR}$ method following APHA's method (APHA 1999). The characterization of the three samples is shown in Table $\mathbf{1}$ measured as instantaneous concentration.

The experiments were carried out with $500 \mathrm{~mL}$ samples in batch mode at bench scale in a jar-test equipment with stirring (at $50 \mathrm{rpm}$ ). The mixing allowed for a velocity gradient of 37.5 , which is typical of stormwater sewers with a flow of $1.5 \mathrm{~m} . \mathrm{s}^{-1}$. Contact times and velocity gradients were chosen to represent conditions inside the stormwater sewers. Temperature was the laboratory's ambient, $25+/-1{ }^{\circ} \mathrm{C}$.

Table 1. Physicochemical parameters and colimetry of raw samples

\begin{tabular}{llll}
\hline Parameters & P01 & P02 & P03 \\
\hline pH & 7.2 & 7.2 & 11.2 \\
BOD (mg. L $\left.^{-1}\right)$ & 33.8 & 230.5 & $<5.0$ \\
TSS (mg.L $\left.{ }^{-1}\right)$ & 30.0 & 46.0 & 6.6 \\
Turbidity (FAU) & 11 & 105 & 19 \\
Salinity (mg.L $\left.{ }^{-1}\right)$ & 123.7 & 98.9 & 57.8 \\
Total Coli. (MPN/100 mL) & $2,400,000$ & $2,400,000$ & 240,000 \\
Escherichia Coli & $2,400,000$ & $2,400,000$ & 1,100 \\
(MPN/100 mL) & & & \\
\hline
\end{tabular}

Table 2. Solvay's PAA Proxitane 1512 Composition.

\begin{tabular}{llll}
\hline Components & Formula & $\mathrm{CAS} \mathrm{N}^{\mathrm{o}}$ & $\% \mathrm{w} / \mathrm{w}$ \\
\hline Peracetic Acid & $\mathrm{CH}_{3} \mathrm{COOOH}$ & $79-21-0$ & 15 \\
Hydrogen Peroxide & $\mathrm{H}_{2} \mathrm{O}_{2}$ & $7722-84-1$ & 23 \\
Acetic Acid & $\mathrm{CH}_{3} \mathrm{COOH}$ & $64-19-7$ & 16 \\
Water & $\mathrm{H}_{2} \mathrm{O}_{2}$ & $7732-18-5$ & 46 \\
\hline
\end{tabular}

The peracetic acid solution used was PROXITANE ${ }^{\circledR} 1512$ (Table 2) supplied by Peróxidos do Brasil Ltda (Solvay Group). PAA doses quoted in this study were always expressed in terms of actual milligrams of the active substance $\mathrm{CH}_{3} \mathrm{CO}_{3} \mathrm{H}$ per litre of water to be treated. The chosen PAA doses of 2, 5 and $10 \mathrm{mg} . \mathrm{L}^{-1}$ were based on studies carried out by Atasi et al (2001); Bel et al (2015); Andreoli et al (2013) and Cavallini (2012b).

Disinfection runs were carried out and stopped sharply when contact time reached 2, 5 and $10 \mathrm{~min}$. The interruption was achieved by the addition of $100 \mathrm{mg} . \mathrm{L}^{-1}$ sodium thiosulphate for PAA breakdown, followed by the addition of $50 \mathrm{mg} . \mathrm{L}^{-1}$ catalase for $\mathrm{H}_{2} \mathrm{O}_{2}$ breakdown, added in this order to avoid PAA degradation of the catalase enzyme. The synergetic effect between the peracetic acid and hydrogen peroxide (present in the commercial PAA) for the disinfection, justified the use of the catalase enzyme to destroy the remaining hydrogen peroxide in each aliquot.

\section{Results and Discussion}

Table 1 shows the basic characterization of the raw water samples used in the study. The physicochemical parameters varied significantly, as well as the concentration of E. Coli. The parameters of samples 1 and 2 were similar to the typical values of domestic sewage, with sample 1 showing lower values. As to the sample at point 3 , this was less concentrated in wastewater-typical contaminants. And while samples of points 1 and 2 had $\mathrm{pH} 7.2$, sample at point 3 surprisingly had $\mathrm{pH} 11.2$. It is likely that the higher $\mathrm{pH}$ value was due to the discharge of wash waters mixed with alkaline cleaning products into the sewers, from a shopping mall close by, where collection point 3 was located.

The unexpectedly high alkalinity of the sample at point 3 showed a set of conditions that had not been tested in previous disinfection studies with PAA, because the effluents of wastewater plants previously studied had a $\mathrm{pH}$ closer to neutral and a uniform composition. This makes the present study particularly useful because it shows the use of PAA for in-situ disinfection of stormwaters for different compositions and contaminations that may well come from different parts of the city. For an in-situ disinfection operation a 
simple remote-controlled PAA gravity dosing-skid would be desirable. It would be convenient to establish a basic set of disinfection conditions consisting of a minimum effective dose for a short contact time, for the treatment of different types of runoff waters.

The inactivation efficiency of $E$. Coli for each dose of PAA for the samples collected at points 1, 2 and 3 is shown graphically in Figs. 1-3. Results are indicated in logarithmic units and were calculated by the ratio between the initial count $\left(\mathrm{C}_{0}\right)$ and the final count $(\mathrm{C})$ of Escherichia Coli $\left(\log \mathrm{C}_{0} / \mathrm{C}\right)$. As expected, and in agreement with previous studies of the use of PAA for

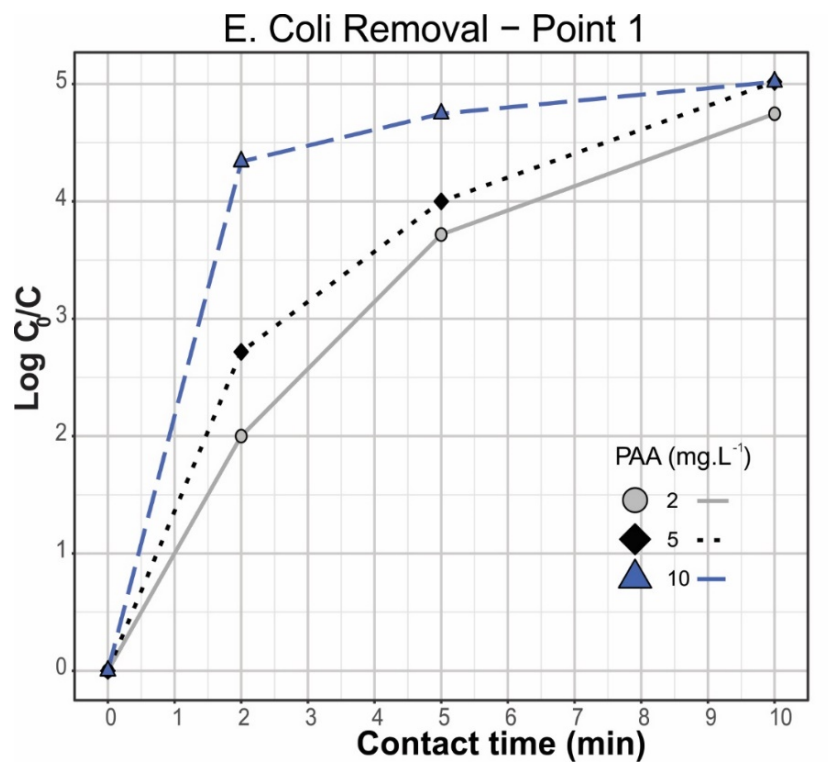

Fig. 1 E. Coli removal versus contact time on sample collected from point 1 for three PAA doses.

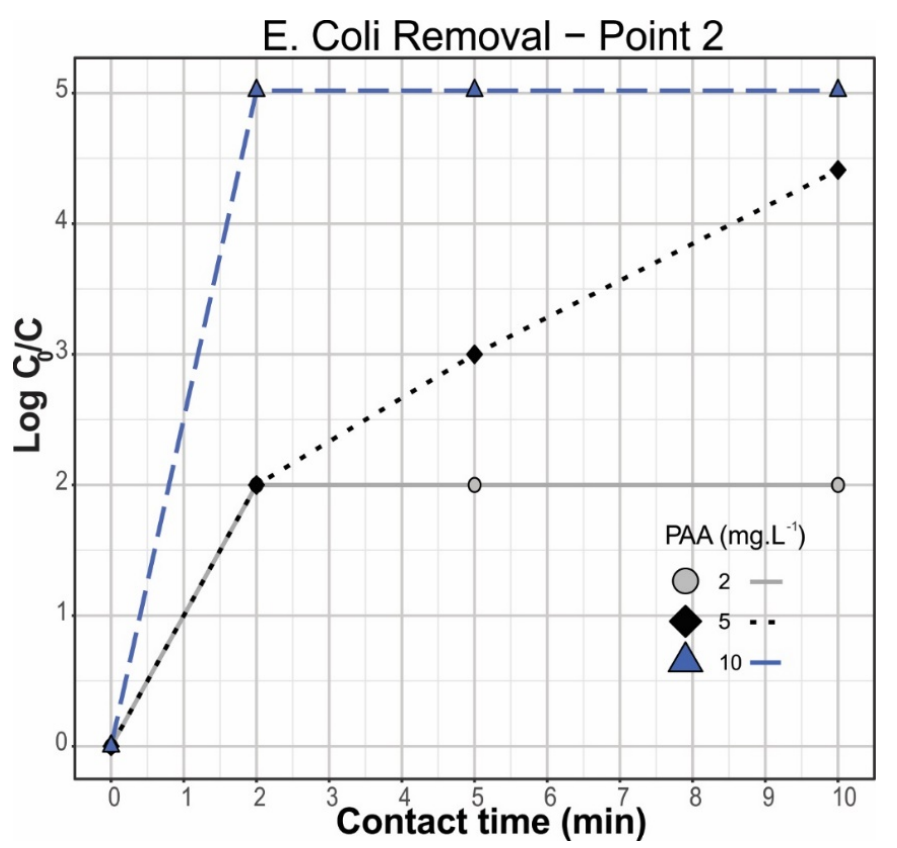

Fig. 2 E. Coli removal versus contact time on sample collected from point 2 for three PAA doses.

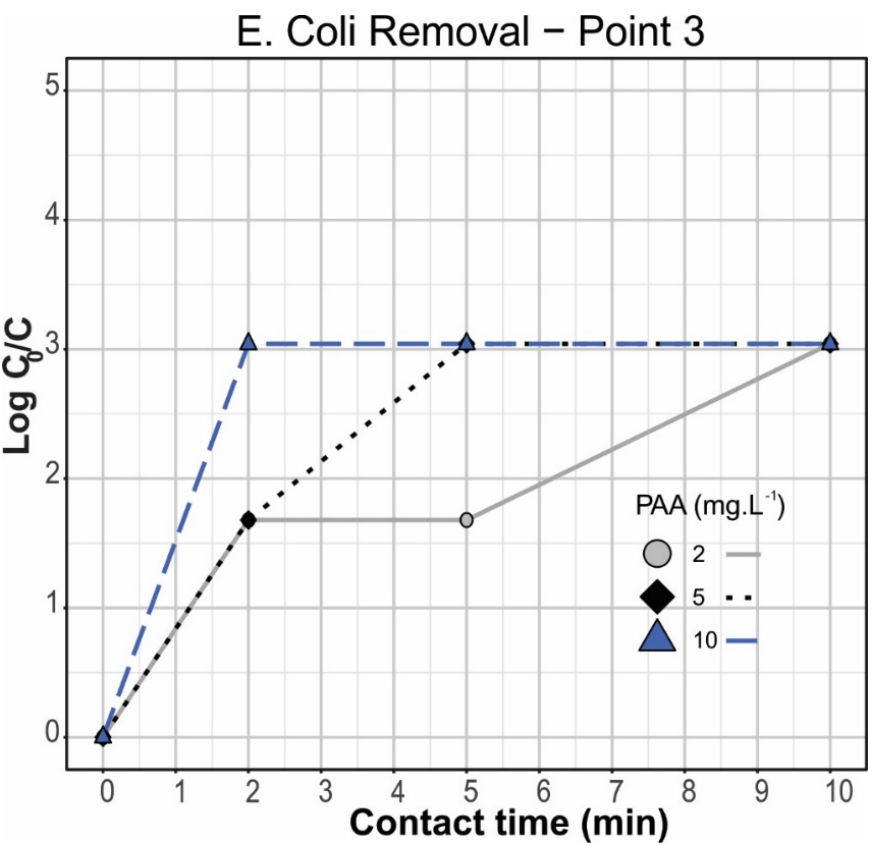

Fig. 3 E. Coli removal versus contact time on sample collected from point 3 for three PAA doses.

disinfection of wastewaters, the disinfection efficiency of our stormwater samples increased with the dosage of peracetic acid and the contact time. For all combinations of dose and contact time (with the exception of $5 \mathrm{mg} . \mathrm{L}^{-1}$ at point 2) the ultimate disinfection efficiency was the same at the end of the observed 10 minutes period.

PAA efficiency for sample at point 2 was the same for doses of 2 and $10 \mathrm{mg} . \mathrm{L}^{-1}$ (Fig. 2). We can observe that the highest possible inactivation achieved for $2 \mathrm{mg} . \mathrm{L}^{-1}$ was $2 \log$ units, which indicates that all peracetic acid was consumed in less than 2 minutes, due to the presence of organic matter in high concentration. The efficiency of a $5 \mathrm{mg} . \mathrm{L}^{-1}$ dose was lower than the efficiency reached by the same dose for sample 1 , as expected; the $10 \mathrm{mg} . \mathrm{L}^{-1}$ dose reached maximum inactivation after only 2 minutes, which is higher than the inactivation achieved for the same dose in sample 1.

The dosage efficiency of $2 \mathrm{mg} . \mathrm{L}^{-1}$ remained constant for samples 2 and 3 , indicating that $2 \mathrm{mg} \cdot \mathrm{L}^{-1}$ of peracetic acid were completely consumed during the initial 2 minutes. That behaviour shows that solid particles on those samples have smaller diameters, enabling oxidation of organic matter by peracetic acid. For all three points, the minimum common dose of PAA required for maximum inactivation efficiency in 2 minutes was $10 \mathrm{mg} . \mathrm{L}^{-1}$.

The differences in disinfection behaviour in samples 1, 2 and 3 may be explained by the negative effects of parameters $\mathrm{pH}, \mathrm{BOD}$ and TSS described by previous authors, as compiled in Kitis's review (2004).

Comparing the disinfection curves of points 1 and 2 for corresponding Figs. 1-2, and especially for the lower doses 2 and $5 \mathrm{mg} . \mathrm{L}^{-1}$, PAA efficiency is 
significantly higher in point 1 . The waters of point 1 and 2 have the same $\mathrm{pH}$, but sample 2 carries significantly higher BOD, TSS and Turbidity, and these three parameters affect disinfection efficiency negatively.

Comparing the curves of point 1 with point 3 for corresponding Figs. 1-3, although BOD, TSS and Turbidity in the water at point 3 are significantly lower than in point 1 , the much higher $\mathrm{pH}$ in point 3 explains the lower efficiency of PAA in this water. At $\mathrm{pH}>8.2$ (the $\mathrm{pKa}$ of $\mathrm{PAA}$ ), the predominant species in the treated water will be the less powerful peracetate ion (compared to the associated acid form).

Finally, comparing points 2 and 3 for corresponding Figs. 2-3, although for sample 2 the values of negatively affecting parameters BOD, TSS and Turbidity are higher by comparison to sample 3 , the higher $\mathrm{pH}$ of this sample results in a lower disinfection efficiency. For the sake of comparison with studies done on wastewaters, the disinfection with a PAA dose of $10 \mathrm{mg} . \mathrm{L}^{-1}$, performed very well. For samples 1 and 2 it reached $5 \log$ units reduction, higher than the results obtained by Atasi et al (2001) and Andreoli et al (2013), for whom doses of 10 to $20 \mathrm{mg} . \mathrm{L}^{-1}$ PAA removed $3 \mathrm{log}$ units of E. Coli in stormwater sewers, and the results obtained by Au et al (2016), with maximum inactivation of $3.65 \mathrm{log}$ units for 15 minutes PAA contact time $(2,3$, 5 and $7 \mathrm{mg} . \mathrm{L}^{-1}$ ) when PAA was added to domestic and industrial effluents after the activated sludge treatment. Coyle et al (2014) observed an average of 4,77 log units of $E$. Coli inactivation with PAA dose of $10 \mathrm{mg} . \mathrm{L}^{-1}$ after 10 min, which was similar to the value obtained with the present work. That information allows us to understand that in effluents with low organic matter (sample 1), contact time was the most important factor for disinfection, whereas in effluents with higher pollutant content (sample 2), dosage is the factor that mostly affects the efficiency of disinfection.

In disinfection it is common to indicate the concentration of the disinfection agent multiplied by the contact time (CT), as mg.min. $\mathrm{L}^{-1}$. This relationship shows that for the set of samples analysed, dosage exerted more influence on disinfection than contact time. A dose of $2 \mathrm{mg} . \mathrm{L}^{-1}$ with 10 minutes contact time reached $1.84 \log$ units, whereas a dose of $10 \mathrm{mg} . \mathrm{L}^{-1}$ with 2 minutes contact time (same CT) reached $3.69 \mathrm{log}$ units, which is equivalent to approximately $15 \mathrm{x}$ higher inactivation value.

Due to the complexity of the response of the microorganisms to the dose of PAA, a simple parametric test would not fit adequately the data generated. Therefore, to get a smoother curve with lower residual errors, a Local Polynomial Regression was performed using non-parametric models, such as the non-parametric regression performed in programming language $\mathrm{R}$ (version 3.6.1) using the
Loess function, with a bandwidth value of 0.75 (Fig. 4) (Wickham, 2016).

Contrarily to parametric methods, a Local Polynomial Regression takes the weighted average of the observations near to the point of interest as a function of distance, with its value represented by the bandwidth (distance window). After defining the bandwidth, a K (Kernel) function should be chosen and, in this case, the Gaussian distribution was selected (Hastie et al, 2009). The input data was data obtained for each sample, with the aim of investigating the relationship between the average efficiency for different doses and the water quality for each sample.

The variation of the physicochemical parameters in the 3 samples was relevant for the evaluation of the efficiency of PAA. Those parameters varied significantly between samples, and sample 2, with a higher concentration of organic matter, showed larger residual variation (indicated by the grey area in Fig. 4).

The curves modelled showed a higher inactivation rate during the first minutes of contact. Models of samples 2 and 3 changed phase after approximately 4 minutes contact time and showed tailing ${ }^{I}$. Cerf (1977) reports that when two homogeneous populations with different resistances are mixed, the inactivation or survival curve shows two phases. It is believed that a group of microorganisms survived disinfection and the population had a tendency to stabilize with the increase in contact time (McFadden et al, 2017).

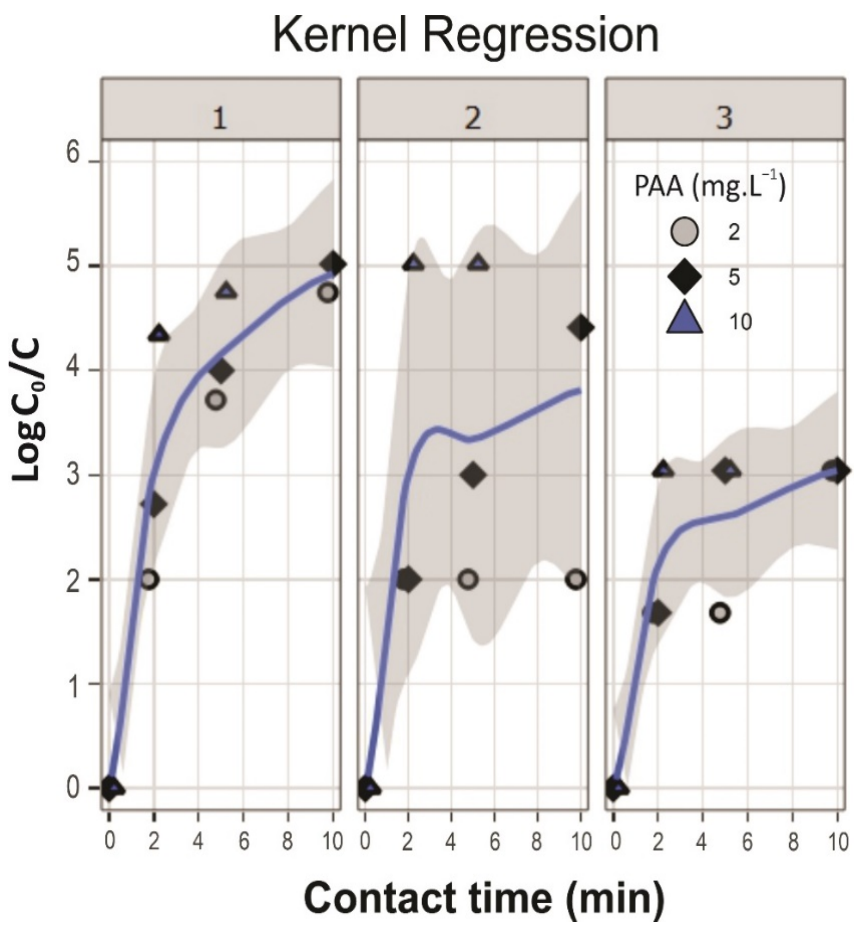

Fig. 4 Local Polynomial Regression by sample point.

${ }^{1}$ Represents colonies that survived disinfection. 


\section{Conclusions}

The evaluation of the possibility of using peracetic acid for the fast in situ disinfection of stormwater runoff contaminated with sewerage by simulating typical hydraulic conditions found in the stormwater sewers was carried out and led to a favourable conclusion.

Peracetic acid performed rapidly, deactivating $E$. Coli on the samples taken from three different points of the stormwater system in a dense residential area close to the shoreline of the city of Rio de Janeiro.

In order to operate a fast in situ disinfection using the stormwater collecting network with a minimum of 2 min contact time, corresponding to a distance of $180 \mathrm{~m}$ from the application point, for typical flow velocity, (a manhole, for example) to the discharge into the water receiving body (a beach, for example), $10 \mathrm{mg} . \mathrm{L}^{-1}$ was a sufficient and viable dose for the three different tested samples.

The use of $10 \mathrm{mg} . \mathrm{L}^{-1} \mathrm{PAA}$ with 2 min contact time allowed a reduction of $E$. Coli from $2.4 \times 10^{6} \mathrm{MPN} / 100 \mathrm{~mL}$ down to less than $100 \mathrm{MPN} / 100 \mathrm{~mL}$ for the two most contaminated samples tested, and from $1.1 \times 10^{3} \mathrm{MPN} / 100 \mathrm{~mL}$ down to $2 \mathrm{MPN} / 100 \mathrm{~mL}$ for the least contaminated sample. These values complied with the minimum level of recreational bathing water quality defined by the Brazilian Standard (CONAMA 274/2000), which limits E. Coli count to less than $800 \mathrm{MPN} / 100 \mathrm{~mL}$ (in the water receiving body).

The results also showed that for interception points in the stormwater collection network farther away from the water receiving body, the application of lower doses of PAA, such as $5 \mathrm{mg} . \mathrm{L}^{-1}$, would be sufficient to achieve the same reduction. These results also support the possibility of centralized fast disinfection of stormwaters in densely occupied residential areas of cities, with the advantage of being able to employ smallsized contact tanks.

We can conclude that the performance of peracetic acid for the E. Coli disinfection of contaminated urban stormwater is fast and efficient, even if that water contains a diverse and complex matrix of pollutants, including a very high $\mathrm{pH}$.

\section{References}

Andreoli, C.V.; Schmitt, C.; Carneiro, C.; Souza, F. S. M.; Pellizzari, F.; Kondageski, J. H.; Marques, P.H. Desinfecção Emergencial de Galeria Pluvial Pela Aplicação de Ácido Peracético e sua Influência na Bacia do Rio Brejatuba Guaratuba - Paraná (Storm drain sewage disinfection by using peracetic acid and hydrogen peroxide, and its impact on Brejatuba basin - Guaratuba - Paraná state, southern brazil. Revista DAE, $n^{\circ} 193$ (2013). In Portuguese

Antonelli, M.; Turolla, A.; Mezzanotte, V.; NURIZZO, C. Peracetic Acid for Secondary Effluent Disinfection: A Comprehensive
Performance Assessment. Water Science \& Technology (68.12), pp. 2638-2644 (2013).

Atasi, K.; Rabbaig, M.; Chen, C. Alternative Disinfectants Evaluations for Combine Sewage Overflow (CSO): Detroit Baby Creek CSO Case Study. WEFTEC 2001. Water Environment Federation. Detroit, 2001.

Au, K.; Block, P.; Oller, P.; Mcpherson, S. Peracetic Acid Wastewater Disinfection to Eliminate Formation of Disinfection By Products at U.S. Naval Mayport Station Wastewater Treatment Facility: Permitting, Trialing and Full Scale Implementation. WEFTEC 2016. Water Environment Federation. New Orleans, 2016.

Baldry, M. G. C.; Cavadore, A.; French, M. S.; Massa, G.; Rodrigues, L. M.; Schirch, P. F. T.; Threadgold, T. L. Effluent Disinfection in Warm Climates With Peracetic Acid. Water Science and Technology. Vol. 31, n ${ }^{\circ}$ 5-6, pp. 161-164 (1995);

Bell, K.; Block, P.; Amador, J. Peracetic Acid (PAA) Disinfection Upgrading WWTPs to Reduce Ecosystem Toxicity. WEFTEC 2015. Water Environmental Federation. Chicago (2015).

Block, S. S. Disinfection, Sterilization, and Preservation. Ed. Lippincott Williams and Wilkins. Philadelphia, Lippincott Williams \& Wilkins, 1481 p. 2001.

Block, D.; Fisher, P.; Evans, K.; Bradbury, N.; Howarth, J. Ecotoxicity of Peracetic Acid to Freshwater Fish, Macroinvertebrate, and Plant Species. Proceedings of the Water Environment Federation in Disinfection. pp. 833-839(7) (2009) doi: https://doi.org/10.2175/193864709793847906

Cavallini, G.; Campos, S. X.; Souza, J. B.; Vidal, C. M. S. Evaluation of the Physical-Chemical Characteristics of Wastewater After Disinfection with Peracetic Acid. Water, Air \& Soil Pollution. v. 224 (2012) doi: 10.1007/s11270-013-1752-5

Cerf, O. A Review Tailing of Survival Curves of Bacterial Spores. Journal of Applied Microbiology, 42(1), 1-19. (1977).

Chhetri, R. K.; Thornberg, D.; Jesper, G.; Robin, G.; Ulrik, R.; Kumari, S. A; Rasmus, A. H. Chemical Disinfection of Combined Sewer Overflow Waters Using Performic Acid or Peracetic Acids. Science of the Total Environment vol. 490 pp.1065-1072 (2014) doi: https://doi.org/10.1016/j.scitotenv.2014.05.079

Coyle, E.E.; Ormsbee, L.E.; Brion, G.M. Peracetic Acid as an Alternative Disinfection Technology for Wet Weather Flows. Water Environment Research, v. 86 ,pp. 687-697 (2014)

Dell'erba, A.; Falsanisi, D.; Liberti, L.; Notarnicola, M.; SANTORO, D. Disinfection By-Products Formation During Wastewater Disinfection with Peracetic Acid. Desalination v. 215, pp. 177-186 (2007).

ECETOC (European Centre For Ecotoxicology and Toxicology Of Chemicals) JACC 040 : Peracetic Acid (CAS No. 79-21-0) and its Equilibrium Solution. Brussels (2001) ISSN -0733-6339-40.

ECHA (European Chemicals Agency). Opinion of the Biocidal Products Committee (BPC). Helsinki (2016).

Falsanisi, D.; Gehr, R.; Liberti, L.; Notarnicola, M. Effect of Suspended Particles on Disinfection of a Physicochemical Municipal Wastewater with Peracetic Acid. Water Quality Research Journal of Canada. vol. 43, $\mathrm{n}^{\circ} 1$, pp. 47-54 (2008).

Hastie, T., Tibshirani, R., \& Friedman, J. The Elements of Statistical Learning. Springer Series in Statistics. (2009) doi:10.1007/978$0-387-84858-7$

Kitis, M. Disinfection Of Wastewater with Peracetic Acid: A Review. Environment International. v.30, pp. 47-55 (2004).

Koivunen, J. \& Heinonen-Tanski H. Peracetic Acid (PAA) Disinfection Of Primary, Secondary And Tertiary Treated Municipal Wastewaters. Water Research. v.39 pp. 4445-4453 (2005).

Luukkonen T.; Teeriniemi, J.; Prokkola, H.; Rämö; Lassi, U. Chemical Aspects Of Peracetic Acid Based Wastewater Disinfection. Water SA. v. 40, pp. 73-80 (2014). 
Luukkonen, T.; Heyninck, T.; Rämö, J.; Lassi, U. Comparison Of Organic Peracids In Wastewater Treatment: Disinfection, Oxidation And Corrosion. Water Research. vol. 85, pp. 275-285 (2015).

McFadden, M.; Loconsole, J.; Schockling, A. J.; Nerenberg, R.; Pavissich, J. P. Comparing peracetic acid and hypochlorite for disinfection of combined sewer overflows: Effects of suspendedsolids and $\mathrm{pH}$, Science of The Total Environment, Volumes 599-600, Pages 533-539, ISSN 0048-9697, https://doi.org/10.1016/j.scitotenv.2017.04.179. (2017).

Nurizzo, C.; Antonelli, M.; Profaizer, M.; Romele, L. By-products In Surface And Reclaimed Water Disinfected With Various Agents. Desalination. v.176, pp. 241-253 (2005).

SNIS (Sistema Nacional de Informações sobre Saneamento). Diagnóstico dos Serviços de Água e Esgotos - 2017 SNSA/MCIDADES 226 p. (2019).

US-EPA, Combined Sewer Overflow Technology Fact Sheet: Alternative Disinfection Methods. US EPA/832-F-99-033. Washington, DC. (2000).
US-EPA, Pesticide Registration. List N: Disinfectants for Use Against SARS-CoV-2. Washington, DC. (2020), viewed 11 April $2020<$ https://www.epa.gov/pesticide-registration/list-ndisinfectants-use-against-sars-cov-2>.

Volschan JR., I.; Figueiredo, I. C.; Santos, D. S. Effectiveness of Peracetic Acid on the Disinfection of Fecal Contaminated Stormwater: A Real Case in Rio de Janeiro City. In: 14th IWA International Conference on Urban Drainage - ICUD, 2017, Prague (2017).

Warish, A.; Nicola, A.; Janette, E.; Kyle, B.; Aaron, B.; Jake, W.O.; Phil, M. C.; Masaaki, K.; Stuart, L. S.; Jiaying, L.; Ben, T.; Rory, V.; Wendy, J.M.S.; Julian, Z.; Leanne, D.; Philip, H.; Kevin, V.T.; Jochen, F.M.; First confirmed detection of SARS-CoV-2 in untreated wastewater in Australia: A proof of concept for the wastewater surveillance of COVID-19 in the community. Science of The Total Environment, 2020, 138764, ISSN 0048-9697, https://doi.org/10.1016/j.scitotenv.2020.138764 (2020).

Wickham, H. ggplot2: Elegant Graphics for Data Analysis. Springer-Verlag. $\quad$ ISBN 978-3-319-24277-4, https://ggplot2.tidyverse.org New York (2016). 